\title{
A REVIEW ON PHYTOPHARMACOLOGICAL SIGNIFICANCE OF ECLIPTA ALBA
}

\author{
A. Umesh ${ }^{1,2^{\star}}$ and MV. Kumudhavalli ${ }^{1}$ \\ ${ }^{1}$ Vinayaka Mission's College of Pharmacy, Vinayaka Mission's Research \\ Foundation (Deemed University) Salem, Tamil Nadu- 636 008, India. \\ ${ }^{2}$ Department of Pharmacognosy, Grace College of Pharmacy, \\ Palakkad, Kerala- 678004, Thiruvananthapuram India.
}

\begin{abstract}
Nature has been a source of medicinal agents for more than thousands of years and herbal therapy predominates in traditional systems of medicine. Eclipta alba Hassk is an important small branched annual herbaceous plant in Ayurveda described first by Bhavprakasha and is widely used for treating various ailments in the Indian system of medicine. Aim: Aim of this review is to provide comprehensive information on the pharmacological activities of various part of Eclipta alba Hassk. Setting and design: This is a contribution which provides a comprehensive review on ethnomedicinal uses, chemical composition, and the pharmacological profile of Eclipta alba Hassk. as an important medicinal plant.
\end{abstract}

Keywords: Eclipta alba, Traditional uses, phytochemistry, pharmacology.

\section{INTRODUCTION}

Conventional medicines play an important role in health services around the world. About three quarters of the world's population is dependent on different parts of medicinal plants and its extracts for wellbeing In India. Medicinal plants have been used in folk medicine since date back in different part of the world against a variety of diseases (Satish A et al., 2016).

Eclipta alba (Asteraceae) is an annual herbaceous plant, commonly known as false daisy. It is an erect or prostrate, much branched, roughly hairy, annual, rooting at the nodes; the leaves are opposite, sessile and lanceolate. It is also known as Bhringaraj and Karisilakanni, which is found a common weed throughout India ascending up to $6000 \mathrm{ft}$. The genus name comes from the Greek word meaning "Deficient," with reference to the absence of the bristles and awns on the fruits. The specific Eclipta alba means white which refers to the color of the flowers. Main active principles consist of coumestans like wedelolactone, desmethylwedelolactone, furanocoumarins, oleanane \& taraxastane glycosides (Mithun NM et al., 2011).
Classification (Sanjivani S et al., 2017; Goutam M et al., 2018)

\begin{tabular}{|l|l|l|}
\hline Botanical name & $:$ & Eclipta alba \\
\hline Common name & $:$ & Bhringaraj \\
\hline Kingdom & $:$ & Plantae \\
\hline Division & $:$ & Tracheophyta \\
\hline Class & $:$ & Magnoliopsida \\
\hline Order & $:$ & Asterales \\
\hline Family & $:$ & Asteraceae \\
\hline Genus & $:$ & Eclipta \\
\hline Species & $:$ & Alba \\
\hline
\end{tabular}

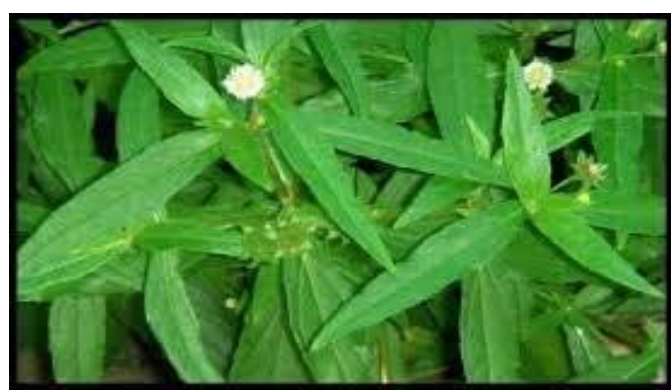

Fig. 1: Plant of Eclipta alba

Traditional uses

In ayurvedic medicine, the leaf extract is considered a powerful liver tonic, rejuvenative and especially good for the hair. A black dye 
obtained from Eclipta alba is used for dyeing hair and tattooing. Eclipta alba also has traditional external uses, like athlete foot, eczema and dermatitis, on the scalp to address hair loss and the leaves have been used in the treatment of scorpion stings. In India, it is grown alongside of rice fields and its leaves are used in preparing food (Shafi $P$ et al., 2016).

\begin{tabular}{|c|c|c|}
\hline S.NO & Parts & CHEMICAL CONSTITUENTS \\
\hline 1. & Leaves & $\begin{array}{c}\text { Stigmasterol, a-terthienymethanol, Wedelolactone [1.6\%], } \\
\text { Desmethylwedelolactone, Desmethyl-wedelolactone-7-glucoside (Upadhyay RK et } \\
\text { al, 2001). }\end{array}$ \\
\hline 2. & Roots & Hentriacontanol, Heptacosanol\& Stigmastero, Ecliptal \\
\hline 3. & Aerial parts & $\begin{array}{l}\text { B-amyrin \& Luteolin-7-0-glucoside, Apigenin, Cinnaroside, Sulphur compounds } \\
\text { (Sikroria BC et al., 1982). }\end{array}$ \\
\hline 4. & Stems & Wedelolactone \\
\hline 5. & Seeds & Sterols \\
\hline 6. & Whole plant & $\begin{array}{l}\text { Large amounts of resin, Ecliptine, Reducing sugar6, Nicotine, Stigmastero, } \\
\text { Triterpene saponin, Eclalbatin together with a-amyrin, Ursolic acid, Oleanolic acid } \\
\text { (Singh P et al., 1988) }\end{array}$ \\
\hline
\end{tabular}

Biological Activites of Parts of Eclipta alba

\begin{tabular}{|c|c|c|}
\hline 1. & Seeds & Sexual debility, Tonic, Aphrodisiac (Khare CP et al, 2004). \\
\hline 2. & $\begin{array}{l}\text { Juice of } \\
\text { Leaves }\end{array}$ & $\begin{array}{c}\text { Skin diseases, allergic Urticaria, Asthma, Inflatulence, Colic and liver affections, } \\
\text { Bronchitis, Enlarged glands, Dizziness, Vertigo, Blurred vision }\end{array}$ \\
\hline 3. & $\begin{array}{l}\text { Paste of } \\
\text { leaves }\end{array}$ & Applied over swelling \\
\hline 4. & Powder & Bronchitis, Cough, Rheumatism and Skin diseases \\
\hline 5. & Decoction & $\begin{array}{c}\text { Invigorate the liver, Graying of hair, To staunch Bleedings, Spermatorrhoea, } \\
\text { Menorrhagia (Chopra RN et al., 1958). }\end{array}$ \\
\hline 6. & $\begin{array}{l}\text { Paste of } \\
\text { herb }\end{array}$ & Healing effect, Headache, Toothache \\
\hline 7. & Root & Liver tonic, Emetic, Purgative, Antiseptic to ulcers, Wounds in cattle \\
\hline 8. & Whole plant & $\begin{array}{c}\text { Rejuvenating, Age-sustaining tonic, Detoxifying, Deobstruent, Antiseptic herb in } \\
\text { vitiated blood, Anaemia, Splenic and liver enlargements, Catarrhal jaundice, } \\
\text { Hyperacidity, Gastritis, Dysentery, Anticatarrhal, Spasmogenic, Hypotensive } \\
\text { properties (Joshi SG et al., ) } 2004 .\end{array}$ \\
\hline
\end{tabular}

\section{Hepatoprotective Activity}

$200 \mathrm{mg} / \mathrm{kg}$ body weight of isolated fraction of Eclipta alba was found to be hepatoprotective against $\mathrm{CCl} 4$ induced hepato damage in rats. The experimental protocol was performed as per CPCSEA guide lines. The results in the present study indicate that $200 \mathrm{mg} / \mathrm{kg}$ body weight doge of the plant extract was able to reduce major elevated biochemical parameters due to the changes associated with $\mathrm{CCl} 4$ induced liver damage in the experimental rats (Joshi SG et al., 2008).

Alcoholic extract of E. alba was found to have good antihepatotoxic activity as assessed in $\mathrm{CCl}_{4}$-induced liver damage in albino rats through liver to body weight ratio, pentobarbitone sleep time, serum levels of glutamate pyruvate transaminase (GPT) and glutamic oxaloacetic transaminase (GOT), alkaline phosphatase (ALP), and bilirubin. In $\mathrm{CCl}_{4}$-administered rats, there was an increase in liver weight, pentobarbitone sleep time, and elevated GOT, GPT, SALP, and serum bilirubin levels. The alcoholic extract at a dose of $200 \mathrm{mg} / \mathrm{kg}$ significantly reversed these effects (Murthy VN et al., 1992 ).

Hepatitis $\mathrm{C}$ virus (HCV) inhibitory activity has been reported for E.alba extract.
Phytochemical analysis of the extract revealed the presence of three compounds, namely, wedelolactone, luteolin, and apigenin. These compounds exhibited dose-dependent inhibition of HCV replicase in vitro, and anti$\mathrm{HCV}$ replication activity in the cell culture system. The results suggest that the plant or individual components have the potential to be used against HCV (Manvar D et al., 2012).

Ethanol extract of whole plant was tested for hepatoprotective effect against paracetamolinduced hepatotoxicity in mice. Treatment with 100 and $250 \mathrm{mg}$ of the extract per $100 \mathrm{~kg}$ body weight showed significant reductions in paracetamol-induced serum alanine aminotransferase (ALT, also known as GOT) levels. At the same time, histopathological studies showed marked reductions in paracetamol-induced fatty degeneration and centrizonal necrosis in liver of extract-treated mice (Tabassum $\mathrm{N}$ et al, 2004).

An alcoholic extract of freshly collected Eclipta alba exhibited dose-dependent (62.5$500 \mathrm{mg} / \mathrm{kg}$ p.o.) significant hepatoprotective activity against carbon tetrachloride-induced liver injury in rats and mice as determined through various tests like hexobarbitoneinduced sleep, zoxazolamine-induced 
paralysis, bromsulfalein (BSP) clearance, serum levels of transaminases, bilirubin, and protein (Singh B et al., 1993).

In $\mathrm{CCl}_{4}$-induced hepatotoxicity in rats, methanol extract of leaves and chloroform extract of roots of $E$. alba showed significant reductions of lysosomal enzymes in serum from the elevated levels induced by carbon tetrachloride. At the same time $\mathrm{CCl}_{4}$-induced elevated serum GOT, GPT, ALP, and bilirubin levels were also restored towards normalization with administration of both extracts (Lal VK et al., 2010).

Aqueous extract of leaves of the plant has been found to offer hepatoprotectivity against paracetamol-induced liver damage. Paracetamol-induced increases in TBARS were reduced by the aqueous extract, and paracetamol-induced decreases in GSH were also reversed by the extract. Catalase was also decreased in paracetamol-treated groups, which was also reversed by coadministration of the extract (Parmar SR et al., 2010).

The alcoholic and aqueous extract of $E$. alba leaves was tested for hepatoprotective activity against paracetamol-induced liver damage in albino rats. The alcoholic extract demonstrated significant hepatoprotective effects. The alcoholic extract-treated rats of group III revealed marked hepatoprotection as there was significant reduction in SGOT, SGPT, ALP, total bilirubin, and direct bilirubin and a significant increase in total protein and albumin as compared to paracetamol treated group (Narayanasamy $\mathrm{K}$ et al., 2005).

A polyherbal formulation (Ayush-Liv.04) containing $E$. alba (along with Clitoria ternatea, Asparagus racemosus, Alpinia galanga, and milk tuttam, i.e., copper containing stone) showed hepatoprotective activity against $\mathrm{CCl}_{4}$ and ethanol induced liver damage in rats. Elevated levels of serum AST, ALT, ALP, acid phosphatase, and bilirubin were significantly lowered in the polyherbal formulationadministered rats (Narayanasamy $\mathrm{K}$ et al., 2005).

The ethanolic extract of a polyherbal formulation containing leaves of Melia azadirachta, seeds of Piper longum, and whole plants of $E$. alba has been evaluated for hepatoprotective effects against $\mathrm{CCl}_{4}$-induced hepatic damage in male albino rats. The substantially reduced levels of SOD, CAT, GPx, GST, and glutathione reductase (GR) due to $\mathrm{CCl}_{4}$ were restored to normal with the extract (Kavitha M et al., 2011).

\section{Anti diabetic activity}

Oral administration of leaf suspension of $E$. alba ( 2 and $4 \mathrm{~g} / \mathrm{kg}$ body weight) for 60 days results in significant reduction in blood glucose, glycosylated hemoglobin $\mathrm{HbA}(\mathrm{I}) \mathrm{c}$. The extract decreases the activities of glucose-6- phosphatase and fructose-1,6bisphosphatase, and increase the activity of liver hexokinase. Thus, oral administration of Eclipta alba possess potent antihyperglycemic activity (Ayodhya S et al., 2014).

\section{Memory Enhancing Activity}

The plant has been reported to contain phytosterol, $\beta$-amyrin, triterpenes such as ecalbatin, echinocystic acid, ursolic acid, flavones such as Luteolin and coumarin such as wedelolactone. Studies was conducted by. The studies concluded that the ethanolic leaf extact of Eclipta alba has memory enhancing activity. Luteolins may be responsible for minimizing cognitive deficits due to cholinergic dysfunctioning. Memory enhancing activity is evaluated by elevated plus maze. Significant reduction in transfer latency indicates that the plant extract have memory enhancing activity (Mathew G et al., 2017).

\section{C.N.S. activity}

Recent studies indicated that the aqueous extract of Eclipta alba and its hydrolyzed fraction at a dose of $300 \mathrm{mg} / \mathrm{kg}$ and $30 \mathrm{mg} / \mathrm{kg}$ p.o., respectively showed nootropic activity in rats (Thakur VD et al., 2005).

\section{Anti-inflammatory, Analgesic and Antipyretic activity}

Eclipta alba (L.) Hassk. (Sanskrit: Bhringaraj) found to contain phytochemicals wadelolactone, eclalbatin, ursolic acid, apigenin, ecliptalbine, verazine and $\alpha-$ amyrin having anti-inflammatory and analgesic properties. Single dose of $500 \mathrm{mg} / \mathrm{kg}$ Eclipta alba produce statistically significant antiinflammatory and almost similar central analgesic activity with disease control and morphine sulphate $(5 \mathrm{mg} / \mathrm{kg}$ s.c.) respectively. The extract did not shown peripheral analgesic and antipyretic activity. Conclusion - Ethanolic extract of leaves of Eclipta alba has antiinflammatory and central antinociceptive activity (Narendrakumar P et al., 2017).

Analgesic activity of alcoholic extract of $E$. alba has been determined through tail flick, hot plate, and writhing methods in rats and mice. In all three methods, the extract at a dose of $200 \mathrm{mg} / \mathrm{kg}$ demonstrated significant analgesic and antinociceptive effects (Pandey PS et al., 1997).

Hydroalcoholic extract of the plant showed significant antinociceptive activity in acetic acid-induced writhing tests in rodent model at a dose of $200 \mathrm{mg} / \mathrm{kg} \mathrm{p.o.} \mathrm{The} \mathrm{extract} \mathrm{further}$ showed analgesic effects in formalin tests, with 
the inhibition occurring in the second phase of the response (Leal L et al., 2000).

The anti-inflammatory effect of the plant was evaluated using carrageenan, mediators such as histamine and serotonin induced paw oedema, and cotton pellet induced granuloma tests for their effect on acute and chronic phase inflammation models in rats. The results indicated potent anti-inflammatory activity of the plant in all the models tested (Kumar SS et al., 2005 ).

\section{Antibacterial Activity}

The aqueous extracts of Eclipta alba showed good activity against S.pyogenes, B.cereus, E.coli and P.aeruginosa. If the dilution was above $1000 \mu \mathrm{g} / \mathrm{ml}$ the extract were considered inactive against S.aureus, K.pneumoniae, P.mirabilis and S.typhi. MBC results were similar to MIC results but in the case of MBC the confirmation was made by absence of growth in culture plates after $24 \mathrm{hrs}$ of incubation at $37^{\circ} \mathrm{C}$. A potent antibacterial and hepatoprotective drug could probably be formulated from the plant extract of Eclipta alba to combat the effects of bacterial and hepatotoxic infections (Manoj KP et al., 2011).

\section{Antioxidant Activity}

The present study investigated the antioxidant potential of the ethyl acetate fraction of the aerial parts Eclipta alba L. Hassk (EA) which was widely used as hepatoprotective plant. EA was orally administered at doses of 50,100 and $200 \mathrm{mg} / \mathrm{kg}(\mathrm{n}=6)$ for 7 days in male Charles Foster rats. The extent of hepatoprotective potential of $E$. alba was studied by assessing the biochemical parameters like lipid peroxides (LPO), superoxide dismutase (SOD), catalase (CAT), glutathione peroxidase (GPx), glutathione reductase (GR), ascorbic acid and $\alpha-$ tocopherol in the liver of rats. Oral administration of the EA significantly decreased LPO and elevated the activity of antioxidant enzymes SOD, CAT, GPx and GR as well as endogenous levels of ascorbic acid and $\alpha$-tocopherol in the liver of male Charles Foster rats. This study has revealed the significant antioxidant potential of Eclipta alba in rat liver (Sandeep majumdar A et al., 2010).

\section{Miscellaneous activity}

An alcoholic extract of the plant showed antinociceptive effect in a dose of $200 \mathrm{mg} / \mathrm{kg}$ in rats (Pandey PS et al., 1997). The plant has been reported to possess antinociceptive, antiinflammatorry and bronchodialator activites, due to the coumarin compounds18. Further studies reported confirmed analgesic activity of Eclipta alba (Sawant M et al., 2004).
Preliminary studies revealed the immunomodulatory activity of methanolic extract of Eclipta alba (Jayatirtha, MG et al., 2004). Wedelolactone and Demethylwedelolactone isolated from Eclipta alba exhibited trypsin inhibition in vitro. Both compounds showed potent activity with IC50 values of 2.9 and $3.0 \mu \mathrm{g} / \mathrm{ml}$, respectively (Syed S et al., 2003).

\section{Toxicity Studies}

In studies conducted the alcoholic extract of Eclipta alba shows no signs of toxicity in rats and mice and the minimum lethal dose was found to be greater than $2.0 \mathrm{~g} / \mathrm{kg}$ when given orally and intraperitonially in mice (Singh B et al., 1993).

\section{Diuretic activity}

Aqueous and alcoholic extracts of the leaf of Ecilepta prostrata leaves were tested for diuretic activity in rats. The parameters studied on individual rat were body weight before and after test period, total urine volume urine concentration of $\mathrm{Na}+, \mathrm{K}+$ and $\mathrm{Cl}-$. Ecilepta prostrata leaves $(100 \mathrm{mg} / \mathrm{kg}$ of body weight) showed increase in urine volume, cation and anion excretion. Furosemide was used as reference diuretic, the plant extracts did not appear to have renal toxicity or any other adverse effects (Vipan K et al., 2015).

\section{Anticovulsant Activity}

E. alba ethanolic leaf extracts at doses of 50 , 100,200 , and $400 \mathrm{mg} / \mathrm{kg}$, p.o., were studied for anticonvulsant and muscle relaxant activity on maximal electroshock-induced seizures (mes), rotarod, and traction test, respectively, in rats. at doses of 200 and $400 \mathrm{mg} / \mathrm{kg}$, the extract reduced seizures induced by mes, decreased the duration of tonic hind limb extension (thle) (by 76.2 and $89.8 \%$, resp.), and decreased motor coordination showing anticonvulsant and muscle relaxant activity (Mishra S et al., 2014).

\section{Hair Growth Promoting Activity}

Petroleum ether and ethanol extract of $E$. albahas been tested in albino rats for promoting hair growth activity. The extracts were incorporated into oleaginous cream (water in oil cream base) and applied topically on shaved denuded skin of male albino rats. The extracts significantly reduced hair growth time by half, as compared to nontreated control animals. Quantitative analysis of hair growth after treatment with petroleum ether extract $(5 \%)$ exhibited greater number of hair follicles in anagenic phase $(69 \pm 4)$ which were higher as compared to control $(47 \pm 13)$ ( Roy RK et al., 2008). 
A polyherbal formulation containing $E$. alba, Hibiscus rosa-sinensis, and Nardostachys jatamansi exhibited excellent hair growth activity in Wistar albino rats. Hair growth initiation time and time required for complete hair growth were significantly reduced. Treatment with the formulation resulted in greater number of hair follicles in the anagenic phase(Thorat RM et al., 2009).

\section{Neuropharmacological Activities}

The aqueous and hydroalcoholic extracts of $E$. alba have been evaluated for sedative, muscle relaxant, anxiolytic, nootropic, and antistress activities at doses of 150 and $300 \mathrm{mg} / \mathrm{kg}$, p.o. The findings indicated nootropic activity of the aqueous extract $(300 \mathrm{mg} / \mathrm{kg}$, p.o.) and its hydrolyzed fraction $(30 \mathrm{mg} / \mathrm{kg}$, p.o.). The aqueous extract and the hydrolyzed fraction were observed to provide protection against cold restraint induced gastric ulcer formation and also normalized the white blood cell count in the milk induced leukocytosis challenge model (Thakur VD et al., 2005).

Aqueous extract of $E$. alba has been tested for its ability to reduce aggression through foot shock-induced aggression and water competition tests. Minimization of aggression in both tests was observed with the extract at doses of 100 and $200 \mathrm{mg} / \mathrm{kg}$ (Lobo OJF et al., 2008).

\section{Anthelmintic Activity}

The methanol extract of whole plant of $E$. alba was evaluated for its anthelmintic potential against the earthworm Pheretima posthuma at doses of $25-100 \mathrm{mg} / \mathrm{mL}$. The extract exhibited paralysis of worms at doses of 50,75 , and $100 \mathrm{mg} / \mathrm{mL}$ and caused death of worms at 75 and $100 \mathrm{mg} / \mathrm{Ml}$ (Ghule SC et al., 2011).

\section{Antiulcer Activity}

The ethanolic extract of $E$. alba has been examined for its antiulcer effects in several ulcer models in rats, like cold resistant stress (CRS) and pylorus ligation (PL). The extract administered orally twice daily at doses of 50 , 100 , and $200 \mathrm{mg} / \mathrm{kg}$ was found to dosedependently and significantly reduce ulcerative lesions. At the same time, extract administration led to significant attenuation of lipid peroxidation and elevated levels of catalase activity. Antisecretory activity of the extract was evidenced by significant reduction in gastric volume, acid output, and increase in gastric $\mathrm{pH}$ when compared to control (without extract) rats (Kumar SP et al., 2012).

The methanolic extract of $E$. alba also showed antiulcer activity in ulcers induced in thirty- six- hour fasted Sprague Dawley rats by aspirin or ethanol or pylorus ligation plus aspirin treatment. In all the three separate experiments the group receiving oral administration of $E$. alba prior to ulcer induction showed highly significant reduction in the occurrence of gastric ulcers as well as gastric inflammation (after $4 \mathrm{~h}$ of treatment) as compared to the control groups. The extract activity was comparable to the activity of the proton pump inhibiting drug rabeprazole (Banerjee A et al., 2005).

\section{Anticancer activity}

The anticancer potential of hydroalcoholic extract of $E$. alba has been evaluated. The extract inhibited the cell proliferation in dosedependent manner in HepG2, A498, and C6 glioma cell lines with an $\mathrm{IC}_{50}$ of $22 \pm 2.9,25 \pm 3.6$ and $50 \pm 8.7 \mu \mathrm{g} / \mathrm{mL}$, respectively.

The expression of matrix metalloproteinases (MMP) 2 and 9 was down regulated significantly. Additionally, downregulation of nuclear factor $\mathrm{KB}$ (NFKB) was also observed. DNA damage was observed following $72 \mathrm{~h}$ of extract treatment, leading to apoptosis (Chaudhary $\mathrm{H}$ et al., 2011).

Juice obtained from $E$. alba was shown to inhibit the migration of HCC-S102 (hepatocellular carcinoma) cells. In various human cancer cell lines of different tissue origins (liver, lung, and breast), the juice inhibited migration of all the cell lines with $\mathrm{IC}_{50}$ values ranging from $31-70 \mu \mathrm{g} / \mathrm{mL}$. Thus the plant has potential for preventing cancer metastasis (Lirdprapamongkol $\mathrm{K}$ et al., 2008).

The ethyl acetate, methanol, and aqueous extracts of whole dried plants of $E$. alba were assessed for their inhibitory effects on the human lung epithelial adenocarcinoma cell line (HCC-827) using the MTT assay. Dosedependent reductions in viable cell count were noticed with all three extracts with the ethyl acetate extract showing the most potency. All extracts induced apoptosis in the cancer cells (Chauhan N et al., 2012).

\section{Antimicrobial Activity}

Various solvent (petroleum ether, benzene, chloroform, acetone, methanol, and aqueous) extracts of $E$. alba were found to be active against clinical isolates from oral cancer cases. These isolates included various bacteria like Staphylococcus aureus, Escherichia coli, Staphylococcus epidermis, Pseudomonas aeruginosa, Klebsiella pneumoniae, Proteus mirabilis, and Proteus vulgaris and funguses like Candida albicans and Aspergillus fumigates (Panghal M et al., 2011). 
Ethanol and ethyl acetate extracts of leaves of the plant have been found to be active against $E$. coli, $K$. pneumoniae, Shigella dysenteriae, Salmonella typhi, $P$. aeruginosa, Bacillus subtilis, and $S$. aureus with Minimum Inhibitory Concentrations (MIC) ranging from 4.5 to $90 \mu \mathrm{L} / \mathrm{Ml}$ (Karthikumar S et al., 2007).

\section{Snake Bite}

Extract of $E$. alba has been shown to inhibit snake venom phospholipase A2 activity of Crotalus durissus terrificus venom. The inhibitory activity has been attributed to the coumestans, wedelolactone, and demethylwedelolactone, present in the extract (Diogo LC et al., 2009).

\section{CONCLUSION}

World Health Organization appreciated the importance of medicinal plants for public health care in developing nations. Eclipta alba (Bhringaraja) having important role in the traditional Ayurvedic and Unani systems of holistic health and herbal medicine.

This review presents some phytochemicals and detailed pharmacological information of Eclipta alba suggesting that the traditional uses of the plant are scientifically valid. Researchers are exploring the therapeutic potential of this plant as it has more therapeutic properties which are not known. This review article suggests that E.alba has been effective in treatment for afore mentioned life threatening diseases. In future the standardization and stabilization studies on Eclipta alba extract can be carried out which can help in proving it to be a promising source in neutraceutical as well as pharmaceutical industry.

\section{REFERENCES}

1. Ayodhya S, Anjali $S$ and Vandana D. Antidiabetic effect of Eclipta alba. International Journal of Scientific and Engineering Research. 2014;5(2):14621466.

2. Banerjee $A$, Shrivastava $N$, Kothari $A$, Padh $\mathrm{H}$ and Nivsarkar $\mathrm{M}$. Antiulcer activity of methanol extract of Eclipta alba. Indian Journal of Pharmaceutical Sciences. 2005;67(2):165-168.

3. Chaudhary $\mathrm{H}$, Dhuna V, Singh J, Kamboj SS and Seshadri S. Evaluation of hydro-alcoholic extract of Eclipta alba for its anticancer potential an In vitro study. Journal Ethnopharmacology 2011:136(2):363367.

4. Chauhan N, Singh D and Painuli RM. Screening of bioprotective properties and phytochemical analysis of various extracts of Eclipta alba whole plant. International Journal of Pharmacy and Pharmaceutical Sciences. 2012;4(2):554-560.

5. Chopra RN, Chopra IC, Handa KL and Kapur LD. Indigenous Drugs of India, 2nd ed, Academic publishers, Calcutta. 1958;78.

6. Deepak $\mathrm{K}$ and Saxena RC. Hepatoprotective activity of ethanolic extract of Eclipta alba in albino rats. Biomedical and Pharmacology Journal. 2008;1(1):235-238.

7. Diogo LC, Fernandes $\mathrm{R}$ and Marcussi SS. Inhibition of snake venoms and phospholipases A2 by Extracts from native and genetically modified Eclipta alba: isolation of active coumestans. Basic and Clinical Pharmacology and Toxicology. 2009;104(4):293-299.

8. Ghule SC, Chaudhari SR and Chavan MJ. Anthelmintic potential of Eclipta alba (L.) Hassk against Pheretima posthuma. International Journal of Pharmacy and Pharmaceutical Sciences. 2011;3(1):143-144.

9. Goutam M, Shymodip K, Argha S, Pintu S, Riyanka S and Chandan K. A review on physicochemical \& pharmacological activity of Eclipta alba, The Pharma Innovation Journal. 2018;7(9):78-83.

10. Jayatirtha MG and Mishra SH. Preliminary immunomodulatory activities of methanolic extracts of Eclipta alba and Centella asiatica. Phytomedicine. 2004;11:361-365.

11. Joshi SG. Medicinal plants, Oxford and IBH Publishing Co. Pvt. Ltd, New Delhi. 2004;81.

12. Karthikumar $\mathrm{S}$, Vigneswari $\mathrm{K}$ and Jegatheesan K. Screening of antibacterial and antioxidant activities of leaves of Eclipta prostrata (L). Scientific Research and Essay. 2007;2(4):101104.

13. Kavitha M, Karimulla SK, Kumar D, Vinoth Kumar S, Sathish Kumar R and Gurucharan M. Hepatoprotective activity of a poly herbal extract in carbon tetra chloride intoxicated hepatotoxicity in male albino rats. International Journal of Pharma and Bio Sciences. $2011 ; 2(3): 307-312$.

14. Khare CP. Encyclopedia of Indian Medicinal plants. Springer-Verlag Berlin Heidelberg, New York. 2004;198.

15. Kumar K, Katiyar AK, Swamy M, Sahni YP and Kumar S. Hepatoprotective effect of Eclipta alba on experimentally induced liver damage in rats. Indian 
Journal of Veterinary Pathology. 2013;37:159-163.

16. Kumar SP, Kumar BS, Chandana VR, Vijaykumar M, Ojha SK and Bavani ME. Antisecretory and antiulcer activities of Eclipta alba Linn. In rats, in Proceedings of the 5th World Ayurveda Congress. Oral Presentation. Abstract No. OA01.03, Bhopal, India, December 2012.

17. Kumar SS, Sivakumar T, Chandrasekar MJ and Suresh B. Evaluation of antiInflammatory activity of Eclipta alba in rats. Ancient Science of Life. 2005;24:112-118.

18. Lal VK, Kumar A, Kumar $P$ and Yadav KS. Screening of leaves and roots of Eclipta alba for hepatoprotective activity. Archives of Applied Science Research. 2010;2(1):86-94.

19. Leal LKAM, Ferreira AAG, Bezerra GAF, Matos JA and Viana GSB. Antinociceptive, anti-inflammatory and bronchodilator activities of Brazilian medicinal plants containing coumarin: a comparative study. Journal of Ethnopharmacology. 2000;70(2):151159.

20. Lirdprapamongkol K, Kramb JP and Chokchaichamnankit D. Juice of Ecl ipta prostrata inhibits cell migration In vitro and exhibits anti-angiogenic activity In vivo. 2008;22(3):363-368.

21. Lobo OJF, Banji D, Annamalai AR and Manavalan R. Evaluation of antiaggressive activity of Eclipta alba in experimental animals. Pakistan Journal of Pharmaceutical Sciences. 2008;21(2):195-199.

22. Manoj Kumar P, Singh GN, Rajeev KS and Sneh Lata. Antibacterial activity of Eclipta alba (L.) Hassk. Journal of Applied Pharmaceutical Science. 2011;01(07):104-107

23. Manvar D, Mishra M, Kumar S and Pandey VN, Identification and evaluation of anti hepatitis $C$ virus phytochemicals from Eclipta alba. Journal of Ethnopharmacology. 2012;144(3):545-554

24. Mathew George, Lincy Joseph and Nimmy Mathew. Review on memory enhancing activity of Eclipta alba. The Pharma Innovation Journal. 2017;6(7):188-189.

25. Mishra S, Jena $M$ and Mishra SS. Evaluation of anticonvulsant and muscle relaxant activities of Eclipta alba using animal models. Indo American Journal of Pharmaceutical Research. 2014;4:1397-1401.
26. Mithun NM, Shashidhara S and Vivek Kumar R. Eclipta alba a review on its phytochemical and pharmacological profile. pharmacological online. 2011;1:345-357.

27. Murthy VN, Reddy BP, Venkateshwarlu $V$ and Kokate CK. Antihepatotoxic activity of Eclipta alba, Tephrosia purpurea and Boerhaavia diffusa. Ancient Science of Life. 1992;11:182186.

28. Narayanasamy $\mathrm{K}$ and Selvi V. Hepatoprotective effect of a polyherbal formulation (Ayush-Liv.04) against ethanol and $\mathrm{CCl} 4$ induced liver damage in rats. Ancient Science of Life. 2005; 25(1):28-33.

29. Narendrakumar P. Paliwal BM, Purohit, Tripathi CB, Hemangini R, Acharya and Mahendra K. evaluation of antiinflammatory, analgesic and antipyretic activity of Eclipta alba (linn.) hassk. in experimental animal. European Journal of Pharmaceutical and Medical Research. 2017; 4(3):391-399.

30. Pandey PS, Pandey KK, Upadhyay OP and Pandey DN. Experimental evaluation of the analgesic property of Eclipta alba Linn Hassk. Ancient Science of life. 1997;17:36-40.

31. Pandey PS, Upadhyay KK and Pandey DN. Experimental evaluation of the analgesic property of Eclipta alba $(\mathrm{L})$ Hassk. Ancient Science of Life. 1997;17:36-40.

32. Panghal M, Kaushal V and Yadav JP. In vitro antimicrobial activity of ten medicinal plants against clinical isolates of oral cancer cases. Annals of Clinical Microbiology and Antimicrobials. 2011;10(21):1-11.

33. Parmar SR, Vashrambhai PH and Kalia K. Hepatoprotective activity of some plants extract against paracetamol induced hepatotoxicity in rats. Journal of Herbal Medicine and Toxicology. 2010;4:101-106.

34. Roy RK, Thakur M and Dixit VK. Hair growth promoting activity of Eclipta alba in male albino rats. Archives of Dermatological 2008;300(7):357-364.

Research.

35. Sandeep majumdar A, Natvarlal Saraf M and Yadav Kamble R. Antioxidant Activity of Eclipta alba L. in Normal Rat Liver. Iranian Journal of Pharmacology and Therapeutics. 2010;9:103-105.

36. Sanjivani $S$ and Shraddha UN. A Phytopharmacological Review of Prospective of Bhringaraj (Eclipta alba 
Hassk.) International Journal of Ayurvedic Medicine. 2017;8(1):01-07.

37. Satish AB, Deepa RV, Nikhil CT and Vaibhav RM. Eclipta alba an overview. International Journal of Bioassays. 2013;02(11):1443-1447.

38. Sawant M, Jolly I and Shridhar N. Analgesic studies on total alkaloids and alcohol extracts of Eclipta alba ( Linn ) Hassk. Phytotherapy Research. 2004;18:111-113.

39. Shafi PM and Imtiyaz A. pharmacological values of Eclipta alba linn (asteraceae) asystematic review. World journal of pharmacy and pharmaceutical sciences. 2016;5(12):504-512.

40. Sikroria BC, Srivastava SJ and Niranjan GS. Phytochemical studies on Eclipta alba. J. Indian Chem Soc. 1982:59:905-909.

41. Singh B, Saxena AK, Chandan BK, Agarwal SG, Bhatia MS and Anand KK. Hepatoprotective effect of ethanolic extract of Eclipta alba on experimental liver damage in rats and mice. Phytotherapy Research. 1993;7(2):154-158.

42. Singh B, Saxena K, Chandan, B, Agarwal S, Bhatia MS and Anand KK. Hepatoprotective effect of ethanolic extract of Eclipta alba on experimental liver damage. Phytother. Res.1993; 7:154-158.

43. Singh P. Naturally occurring thiophene derivatives from Eclipta alba species. Bioact, Mol. 1988;7:179-186.
44. Syed S, Deepak M, Yogisha S, Chandrashekar AP, Muddarachappa KA, D'Souza P, Agarwal A and Venkataraman BV. Trypsin inhibitory effect of wedelolactone and demethylwedelolactone. Phytother. Res. 2003;17:420-421.

45. Tabassum $\mathrm{N}$ and Agrawal SS. Hepatoprotective activity of Eclipta alba Hassk. against paracetamol induced hepatocellular damage in mice. JK Practitioner. 2004;11(4):278-280.

46. Thakur VD and Mengi SA. Neuropharmacological profile of Eclipta alba (Linn.) Hassk. Journal of Ethnopharmacology. 2005;102(1):2331.

47. Thakur VD and Mengi SA. Neuropharmacological profile of Eclipta alba (Linn) Hassk. J. Ethanopharmacol. 2005;102(1):23-31.

48. Thorat RM, Jadhav VM and Kadam VJ. Development and evaluation of polyherbal formulations for hair growthpromoting activity. International Journal of PharmTech Research. 2009;1(4):1251-1254.

49. Upadhyay RK, Pandey MB, Jha RN and Pandey VB. Eclalbatin, a triterpene saponin from Eclipta alba. J Asian Nat Prod Res. 2001;3:213-217.

50. Vipan KS, Sangeeta V, Shweta VM and Mohan LJ. A review on traditional and folklore uses, phyto-chemistry and pharmacology of Eclipta alba hassk. International Ayurvedic Medical Journal. 2015;3(8):2463-2469 . 